\title{
Did Wigan have a Northern Soul?
}

\section{Introduction}

The town of Wigan in Lancashire, England, will forever be associated with the Northern Soul scene because of the existence of the Casino Club, which operated in the town between 1973 and 1981. By contrast, Liverpool just 22 miles west, with the 'the most intensely aware soul music Black Community in the country', (Cohen, 2007, p.31 quoting from Melody Maker, 24 July 1976) remained immune to the attractions of Northern Soul and its associated scene, music, subculture and mythology. Similarly, the city of Manchester has been more broadly associated with punk and post-punk. Wigan was and remains indelibly connected to the Northern Soul scene with the Casino representing a symbolic location for reading the geographical, class and occupational basis of the scene's practitioners. The club is etched into the history, iconography, and mythology of Northern Soul appearing in the academic and more general literature, television documentaries, memoirs, autobiographies and feature films.

This chapter seeks to explore the relationship between history, place, class, industrialisation, mythology and nostalgia in terms of Wigan, the Casino Club and the Northern Soul scene. It asks the question: did Wigan have a northern soul? This is explored through the industrial and working-class history of the town and the place of soul music in its post-war popular culture. More broadly, it complements the historical literature on regional identity identifying how Northern Soul both complemented and challenged orthodox readings of Wigan as a town built on coal and cotton that by the 1970s was entering a process of deindustrialisation.

\section{The road to Wigan pier: coal, cotton, canals and working-class culture}

In the popular imagination, Wigan has long been synonymous with cotton mills, coal mines and working-class culture. This has provided a template for writers attempting to understand and reconstruct a semi-mythical history of close-knit communities, labour politics and the leisure pursuits of industrial workers. The shadow of George Orwell looms large over Wigan's past and present. He spent time in the town in 1936 and published The Road to Wigan Pier a year later. He claimed that 'when you go to the industrial North you are conscious, quite apart from the unfamiliar scenery, of entering a strange country' (Orwell, 1975, p. 98). Orwell painted vivid depictions of the landscape and the everyday life of its coal miners and cotton workers: 'the monstrous scenery of slag-heaps, chimneys, piled scrap-iron, foul canals' (Orwell, 1975, p. 16). This has proved to be a durable lens for later social observations and polemics concerning the 'state of the nation'. Unsurprisingly such imagery has seeped into the visual markers of the Northern Soul scene.

Orwell noted the importance of music and entertainment to the culture of the town along with its peculiarities and differences with the south: 'there was a floating clientele of commercial travellers of the poorer sort, travelling actors - always common in the North 
because most of the larger pubs hire variety artists at the weekends' (Orwell, 1975, p. 10). Images of an embryonic teenage culture were also evidenced through the 'youth who leaves school at fourteen ... but for two pounds ten ... can buy himself a suit ... and at a little distance, looks as though it had been tailored in Savile Row. The girl can look like a fashion plate at an even lower price' (Orwell, 1975, p. 79). For Orwell, this represented a form of quasi-escape, 'a private daydream' that monetarily transported the cotton worker and coal miner from the workplace and the drudgery of the domestic sphere to the fantasy of the metropolis and the Hollywood screen. Forty years later, observers would make similar claims for youths attending Northern Soul 'all-nighters' (frequently Americanised to 'allniters') at the Casino Club.

In the 1950s, elements of Orwell's Wigan were complemented by the arrival of American rhythm and blues, rock ' $n$ ' roll, coffee bars, jukeboxes and a vibrant youth culture epitomised by the Teddy Boy and the dance hall scene. In 1954, the American All Coloured Revue Show visited the town. The local press provided a vivid description of the performance: 'the accent is on rhythm. Dancing is of a very high order and quite uninhibited ... the music contains all that wonderful inspiration for what coloured people are so justly famous' (Wigan Examiner, 11 May 1954). Here was an example of the ways in which the northern industrial working-class absorbed elements of African-American culture as a source of excitement, danger, sexuality and temporary escape through sound, dance and vision.

With the advent of a clearly defined youth culture in the 1960s, there were still around twenty-five collieries in the Wigan district. In this corner of north west England, the landscape and the soundscape formed a strange juxtaposition of Victorian industrial might, colliery head gears, imposing mills and American rhythm and blues music that found its way into the workplace, the home, the workingmen's clubs and the temples of popular entertainment. The Wigan Ritz had opened in 1938 and twenty years later was the scene of an electrifying performance by Buddy Holly and the Crickets. In the following years, the town welcomed The Rolling Stones and The Beatles to venues such as the ABC Theatre and the Empress Ballroom (which later became the Wigan Casino Club).

The formal link between the sounds of American rhythm and blues of the 1960s and the Northern Soul scene of the 1970s was the performance of the Motortown Revue in April 1965. The tour was widely regarded as a disaster with poor ticket sales in many venues. Wigan was no different, with the local press noting that although the performances were gaining rave revues the audience was sparse. The bill consisted of The Supremes, Martha and the Vandellas, Stevie Wonder, the Miracles, and Earl Van Dyke. These artists would later provide elements of the sound, style, lyrics, and mythologies of Northern Soul. These now legendary artists were complemented by Georgie Fame and the Blue Flames. Fame (formerly Clive Powell) had been born in the neighbouring town of Leigh. His biography provides a bridge between Orwell's Wigan and the affluence and modernity of the 1960s. He had worked in a cotton mill and absorbed the working-class culture of the industrial north, the cosmopolitan milieu of London's Soho, and the nascent mod subculture between 1960 and 1964. 
Rhythm and Blues music in Wigan was consumed in formal musical spaces such as the Empire, the $A B C$, and the Ritz, but also through the more traditional transmission routes of working class-culture. The clubs and pubs associated with certain occupations embraced the shifting tastes of local youths with beat groups performing to mixed generational audiences at weekends. American popular music more generally created the pulse and vibrations that sound tracked 'thrill rides' such as the Waltzer and the Speedway that were a feature of Silcock's fairs. The Silcock brothers had been operating pitches close to local Wigan coal mines and cotton mills since the First World War. 'By the late 1950s, bright lights, rock ' $n$ ' roll, and images of American acted as a magnet to the miners and factory workers' (Gildart, 2013 , p. 30). For some, the fair was a first introduction to the rhythm, drama, and energy of what would form the core components of the Northern Soul sound.

The opening of Wigan Casino and its central place in the iconography of Northern Soul complemented the working-class history of the town. The location of the club symbolised the 'northern-ness' of the subculture and its inherent capacity for creating and reinforcing particular mythologies around class and authenticity. When the club established its all-night sessions in the autumn of 1973, Wigan retained many of the hallmarks of an industrial past. The contemporary economic and political situation where trade unionism, the labour movement, and industrial militancy was still a potent force, was a reminder of the resilience of class identities in Wigan in particular and the industrial north more generally.

\section{Northern Soul and the Wigan Casino}

The Northern Soul scene emerged in Britain during the late-1960s and is largely associated with youth subcultures of the 1970s. Following the musical output of American labels such as Motown and Stax it championed American soul music recorded by obscure artists on rare recordings which were not commercially successful but sought after by collectors. Towards the end of 1960s this was known as the 'rare soul' scene. This 'soul underground' was of keen interest to mods in major British towns and cities. As musical preferences and tastes changed interest in 'rare soul' in the south waned in favour of more contemporary African American popular music. However, mainly, but not exclusively, in the North and parts of the Midlands, interest in 'rare' 1960s soul continued to flourish. As Shapiro notes:

young men from the post-industrial wastelands of the north of England worshipped American soul records - the rarer and more obscure the better with a zeal and piety that would shame anyone but the most devout religious followers. (Shapiro, 2005, p.37)

The term 'Northern Soul' has been ascribed to Dave Godin. In 1970 Godin, a leading soul record collector and promoter in London, noticed that many of his customers from the north were keen on obtaining 'rare soul' recordings with a specific sound and coined the phrase 'Northern' Soul'. Northern Soul was primarily dance music and five principal clubs were key to its development: The Twisted Wheel club in Manchester 1963-1971; Blackpool Mecca 1971-1977; the Golden Torch, Stoke-on-Trent 1965-1973; Cleethorpes Pier and Winter Gardens 1975-1977; and most famously Wigan Casino Club, 1973-1981. 
The first all-night soul session at the Casino Club in Wigan was on 22 September 1973. It came at a time when the 'rare soul' scene was already quite well established in the north of England and north Midlands. Wigan had no specific antecedents as a 'rare soul' centre. Like other sizeable urban conurbations, it had its mod hang outs and scenes particularly the Room at the Top Club, (Wiganworld, 2017) which had gained something of a reputation as warm-up venue for 'rare soul' fans before they journeyed to the Twisted Wheel in Manchester (Manchester Beat, 2017). Yet, the opening of the Casino was something of a 'fluke' (Jelbert, Guardian, 2010). A legal loophole meant that all-nighters were permitted as long as alcohol wasn't served; the availability of an elderly dance hall which had been earmarked for closure and demolition by the local council as early as 1965 to make way for town centre redevelopment (Wigan Observer, 27 August 1965); some sagacity by the owners in realising its potential as a modern soul dance venue,(Ritson \& Russell, 1999) and the cavilling and impetus of Russ Winstanley a local record dealer and DJ in encouraging the initiation of all-night soul sessions at the venue (Blues \& Soul, Issue 234, September 13-26 1977). What has been described as a 'no frills, dance hall that had frankly seen better days', (Nowell, 1999) subsequently saw a meteoric rise in popularity aided by the towns' central location, bus and two railway stations and the expanding motorway network of the 1970s.

Wigan Casino presided over the five years from 1973 to 1978 when Northern Soul reached the height of its popularity with the club regularly attracting over 1,500 fans each Saturday night. It has been estimated that in 1975 Northern Soul attracted a combined total of attendance of 100,000 at its various venues, (Hewitt, 2000, p.141) and by 1978 the Casino alone could claim a membership of 100,000 (Blues and Soul, Issue 261, September 26 October 9 1978). The Casino styled itself as the 'Heart of Soul' during this period (Blues and Soul Issue 137, June 18-July 1 1974) running its famed Saturday all-nighters described by Brewster as 'the mother club of the emerging Northern Soul scene' (Living for the Weekend,2014). It was also significant for the large numbers of fans who visited the venue from all over Britain. (Milestone, 1998); (Nowell, 2016) It has been estimated that those travelling to the club from outside the Wigan area was in the 85-90 per cent range with low levels of participation from within the town (Nowell, 2016).

By 1976 the club had gained a nationwide reputation for its 'all-nighters', frenetic dancing to 'rare soul' sounds, the arcane and dilapidated nature of its surroundings, and its northern parochialism. It became a peculiar amalgam of the 'old' and the 'new'. Members also opted largely for a more fundamentalist approach to what they believed constituted Northern Soul in terms of its music policy as opposed to what was perceived as a more contemporary and progressive turn taken at other Northern Soul venues, most notably Blackpool Mecca, with whom which there arose a rivalry resulting in a schism in the scene. The Casino's preference for a particular sound tended to reinforce the view that it had firmly anchored itself to a specific style from which it was unlikely to diverge.

Northern Soul generally and the Casino in particular engaged in a self-perpetuating nostalgia based around anniversary dates such as those related to the first all-nighters (Blues and Soul, Issue 234 , September 13-26, 1977). While the scene was by nature retrospective the Casino's first anniversary opening in September 1974 of a dedicated 'oldies' room in Mr 
Ms,(1) specialising in soul sounds from a narrowly defined time period around the midsixties or playing those sounds which had been popular at antecedent soul venues, (Milestone, 1998) together with a Friday all-nighter with an exclusively 'oldies' format from February 1976 (Shaw, 2023, p.81) tended to reinforce the view that Wigan was an almost exclusively 'oldies' venue by the late 1970s. Many of the Casino's DJing roster attempted to 'break in' new soul discoveries originating from the 1960s (Brewster \& Boughton, 2012) described as 'newies' - or spun more contemporary soul sounds from the 1970s, (Brewster \& Boughton, 2012) but moves away from a strictly retrospective stance were at best unwelcome and at worse vehemently opposed, leading to Cosgrove commenting that Wigan became primarily renowned as 'a citadel of great sixties soul' (Cosgrove, 2016, p.89). By the late 1970s whatever else divided opinion within the scene the Casino's critics were convinced that it had become so bridled to a narrowly time specific soul sound that it was hastening the scene's demise as the Casino and the music it championed had effectively run its course (Brewster \& Broughton, 2006). Contrarily, the Casino's aficionados saw this tendency as something to be celebrated rather than decried right through to the dying embers of the club and its final closure in 1981.

As if to give an underlying context to this debate, in 1977 the club was the subject of a documentary directed by Tony Palmer, and produced for Granada Television's This England series simply entitled 'The Wigan Casino'. The film caused some controversy at the time within the Northern Soul scene (Pilgrim, 2003). It divided opinion as to whether it offered a true representation. Palmer posited Northern Soul very much in terms of class and 'northerness'. For Sanjek, Palmer's focus presented 'working class signifiers' right down to the dancers 'muscles, sweat and tattoos' (Sanjek, 2012, p.232). The film depicted an arcane 'northerness' as the main point of reference for Wigan and its Casino Club, moving Tim Brown, to observe that the legacy of the film was one consumed by 'sparking clogs and oldmill references' (Keep on Burning, 2012). While a debate raged over the film, it established a standard view of the Casino and stands as a definitive reflection for many including those who are now more tolerant of its legacy.

\section{'Them Soulies'}

While the Casino seemed to fit almost seamlessly into Wigan's 'northern' image a chasm developed between the club and its locality. The town in the 1970s had hardly begun to shake off its association with coal and cotton with its economy in serious decline from the late-1960s (Lancashire and Merseyside Development Association, LAMIDA, 1967). At the same time Wigan, unlike its neighbouring cities of Manchester and Liverpool, was less cosmopolitan in both composition and outlook. Similarly, it did not attract visitors in large numbers such as the seaside resort of Blackpool. Nightlife revolved around pubs, labour and working men's clubs and late-night discotheques with an emphasis on alcohol and hedonism. Into this milieu thousands of Northern Soul fans - 'soulies' as described by locals descended every Saturday from all over Britain. A sense of 'us' and 'them soulies' soon developed. On the surface this 'othering' was based on the nightlife preferences of the young. Yet, it was also indicative of a clash between two working-class youth cultures: a 
traditional one based on heavy drinking, rigid gender divisions and overt masculinity and another driven by amphetamine, exclusivity, and elitism.

The primary objective of a night out in Wigan was a drinking and sexual encounter, whereas at the Casino the music and dance were central features. The club also became infamous for the consumption of illegal drugs - mainly, but not exclusively, amphetamine-based - with the intention of staying awake and dancing throughout the night. The Casino attracted youths with different accents and attired in a unique way, which clearly also marked them out from punks and heavy rock fans especially as one part of the Casino building, was, from 1975, used for Saturday evening rock nights. (Zani, 2017) These fans fractiously 'rubbed shoulders' with the 'soulies' into the frequently tense and sometimes dangerous late Saturday evenings (New Soultime, Number 3, 1976?).

The scraps and scrapes which developed mainly at pub closing time as the 'soulies' arrived or gathered in late night cafes waiting for the Casino to open were perhaps predictable. These episodes, however, hid underlying feelings of elitism from the 'soulies' towards locals. As Shaw observes:

These were lads who used to pick fights with the soul crowd who walked up Station Hill to the Casino from the trains. A good night out for them was sinking fifteen pints, staggering to the fish and chip shop and starting a ruck [fight] on the bus home ... There was nothing more profound about them than the depth of their pint-pots or Bacardi and Cokes. I loathed them (Shaw, 2003, p.124).

In this context the local council began to develop a critique of the Casino. For many locals the notion of the 'all-nighter', without alcohol in a dance venue which venerated a particular genre of music through a distinctive scene, together with consumption of illegal drugs, was problematic, with attitudes varying towards the scene ranging from one of bemusement with what appeared to be observably 'strange' to one of downright aggression. From the local council's perspective, the Casino became an 'issue' through the traffic congestion and late-night problems it created in the town centre, (Pilgrim,2003) but more particularly because it became significant as a centre for the consumption of illegal drugs to the extent that Wilson has asserted that:

... in 1975, all the ingredients were assembled: drugs death, teenagers attending an all-night club, angry and concerned parents, MP and media interest' (Wilson, 2007, p.43).

By the end of the decade the Casino's notoriety for drug misuse was widespread. A solicitor defending a 17-year-old girl at Manchester magistrates court for dishonestly handing drugs alleged to have been stolen from a doctor's car was said to have been introduced to the 'drugs sub-culture' at Wigan Casino (Wigan Observer, 7 March 1978). This could be read as another episode in the cycle of moral panics associated with youth culture, yet there is no doubt that the club for all its claims of 'soul togetherness' could be a gritty and edgy place. As Nowell has noted 'The boys had attitude and they were not types that you hoped that your daughter would bring home for afternoon tea' (Nowell, 2002). Similarly, Mason has commented that 'there were some tough bastards at Wigan', some of whom were involved 
in a grim and grubby drugs scene at the venue, (Mason, 2013) while Wilson has identified aspects of the scene, even a specific area within the Casino, which was largely controlled by drug abusing criminal elements (Wilson, 2007, pp.156-160).

There has been a debate about the extent of drug abuse at the Casino, although the weight of opinion seems to point in the direction of drug abuse being 'substantial' or 'rife' (Wilson, 2007); (Nowell, 2016); (Armitage et al, 2017). However, the notion of a music scene, still less a music dance scene, with a drugs association, is hardly unusual. The significance of Northern Soul's link with drugs is that it became a convenient stick for the police and local authorities with which to beat the scene. In this respect it was enough for the local council to contemplate closure of the venue (Wigan Observer, 15 September 1978). This also served to exacerbate the growing gulf between scene and locale. This distance was best expressed as a feeling of 'otherness' in Wigan towards the 'soulies'. As one sixteen-year local lad delivering Sunday morning newspapers recalls in his first encounter with the mythical 'soulies':

Strangely attired and accented out of towners wandering the streets of Wigan asking for directions to the swimming baths at 9 in the morning with eyes like saucers' [ due to being drug addled] (2) (Charlson, 2017)

Such encounters left indelible memories, myths and legends and nourished the narrative of 'otherness'. Nowell, describes 'soulies' leaving Wigan by car on Sunday mornings and descending on a nearby motorway service area looking 'hollow-eyed' and 'knackered' from the night's activities drawing 'strange looks from ordinary clientele' while 'mums and dads' were 'eying you with suspicion and practically hiding their children behind them and whispering: Keep away from them, they've been to that Wigan Casino place' (Nowell, 2015, p.122). There was something not only 'extraordinary' about 'Them Soulies' from a local perspective; they were aliens who inhabited a nocturnal world where 'proper' people should not venture. From the perspective of the early twenty first century, it seems astonishing how this view has dramatically altered.

\section{Northern Soul Resurrected}

In the 1980s, Northern Soul moved out of the national spotlight and returned to its underground roots sustained by a few leading venues and enthusiastic DJs and followers. The Casino's closure in 1981 heralded the much clichéd 'end of an era'. It was not until the late 1990s when interest in Northern Soul re-emerged both for the original 'crowd' and a new generation of followers. While not all this re-kindled interest was nostalgic much of it was at least nostalgically tinged. Central to this has been renewed interest in Wigan Casino in the town itself where many locals had once rejected the scene. Northern Soul venues and 'revival' nights' and 'niters' have proliferated becoming a regular fixture of the town's nightlife (The Swinley, 2016). Visiting Northern Soul fans are now more likely to be greeted by locals with an embrace and tears of joy like some long-lost brother or sister. August 2017 saw a major all-nighter event at the town's roller rink which the local press enthused was a: 
'all-night-long' 'Northern Soul gig'.....as the.... 'scene returns to its glory days with a 10-hour musical marathon' ....and.... 'likely to see 1,000 fans who have kept the faith travelling from far and wide to dance all night to rare, vinyl only soul records' (Wigan Observer, 22 August 2017).

In terms of expressing nostalgic interest in a music scene, there is nothing remarkable about this. However, when it comes from within a town that spent much of the 1970s despising Northern Soul it is of paramount interest. This change of heart could be easily dismissed as marking nearly half a century of changing social attitudes to drug abuse, youth or reinvigoration by local 'soulies'. In Wigan's case, it appears more profound. There is now a widespread belief in the town that Northern Soul forms an integral part of the cultural history of Wigan and is indigenous to it. Significantly, the local rugby league club, Wigan Warriors, itself a traditional and iconic fixture of the town's cultural history, has paid homage to the town's Northern Soul 'tradition'. In 2006 before one Friday evening fixture at the team's JJB Stadium pre-match entertainment was provided by a soul band performing 'Northern Soul Classics'. A club spokesperson adding:

We regularly consult with fans to discover what themes they want to see as prematch entertainment and a Northern Soul production, with its roots strongly in Wigan culture, has always ranked high on the list (Wigan Warriors, 2006).

As with Rugby League, George Orwell and its mythical pier the Northern Soul narrative has become inexorably meshed into the Wigan's cultural history. Jimmy Radcliffe's iconic anthem 'Long After the Night is All Over' fills the evening air as crowds decant from the stadium after a Wigan Warriors game as if this song is now the unofficial anthem of the town and its association with Northern Soul. (3) Similarly, Northern Soul has entered the cultural domain of Wigan through the work of local artists, (Wigan Casino Art, 2017) as well as business branding, including the symbolic Casino Café opened within the Grand Arcade, the town's latest shopping development built on the site of the now demolished club.

If the people of Wigan have to a greater degree now accepted Northern Soul's place in the heart of the town then the local council, one time implacably opposed to it, have gone further by encouraging the scene to flourish. The Monaco Ballroom in nearby Hindley, traditionally an iconic dance and live band venue in its own right, has now become the main Northern Soul venue in the Wigan area and a latter-day soul quasar including replicating anniversary nighters, a kind of Wigan Casino in miniature. Perhaps, more remarkable these soul nights operate under the auspices of Wigan Cultural and Leisure Services Trust - a charity associated with Wigan Council (Milewczyk, 2006). The local authority is now at the forefront of leading the cultural renaissance of Northern Soul. In 2010 the Guardian reported that Tony Palmer, director of the original 1977 documentary, was moved to comment on the volte-face in attitudes and highlighted the role of the local authority: 
A thriving nostalgia industry has built up over the years around its memory, culminating in a public showing of the film last year. "We showed it on the site of the Wigan Casino" says Palmer. To his surprise hundreds of people turned up, including the town council's head of cultural amenities. "At the time they thought it was giving Wigan a bad image "(Jelbert, Guardian, 2010).

It would be churlish to deny Northern Soul's rightful claim to a place in the town's cultural history. By contrast, the appropriation of the Northern Soul mantle by the town should at the very least be greeted with a degree of scepticism. For many 'soulies' of a certain longevity that scepticism might give way to disbelief in relation to how they were received and perceived by the town during the 1970s.

Armstrong, writing of modern day social injustice, asks what is the 'modern' function of former industrial communities: what more do we expect of Wigan? Into this lacuna, what we are left with is the appropriation and promotion of cultural capital, in the case of Wigan by its association with a specific subculture. This has echoes of developments elsewhere in the UK and North America. In Liverpool, for example, Cohen, has written of Liverpool's more established and extensive 'culture-led urban regeneration' over the past 30 years through popular music and specifically through the legacy of The Beatles (Cohen, 2007, pp.129-130). As in the case of Wigan 'the cultural-led agenda' is an illusion when set against the reality of long-term economic decline, economic exclusion and social injustice. In Liverpool the 'reality' is as Danziger has described, with some poignancy, on seeing the 'anonymous graffiti' on entering the city 'speak to us of the ghettos' pain and frustration' (Danziger, 1997, p.187). Similarly, in neighbouring Manchester urban renewal and gentrification of the city has been an agenda which has largely proceeded 'excluding the poor' (Mellor, 2002, pp.230-233).

Reprising the memory of the past Northern Soul scene in the service of the present in Wigan is as much a contrivance as the scene's arrival was in the town during the 1970s. However, to leave this discussion solely in the realm of changing local attitudes toward Northern Soul or contemporary urban political discourse, important though these are, would be to ignore a more complex question as to whether the experience and practice of Northern Soul revealed characteristics within the scene that might be linked to conceptions of 'northerness' and place it more firmly at the town's heart.

\section{The return to Wigan Pier: the north and Northern Soul}

Orwell himself could have been writing about Northern Soul and Wigan Casino when he stated in 1937 that there 'exists in England a curious cult of Northerness' (Orwell, p. 98). A similar characterisation of the northern soul scene was provided by the New Musical Express in 1974 in what it referred to as 'the funky freaks of the Far North'. (New Musical Express, 29 June 1974) This fascination with cultural difference in the specific youth cultures of the North West was further explored, caricatured and mythologised in Palmer's film in 1977. The 'othering' of the town and its 'northern soul' drew heavily on the tropes adopted by Orwell on his road to Wigan Pier: coal miners, dirt, poverty, death, danger, subversion, hedonism, fatalism. These sometimes clumsy attempts at presenting the continuities in the 
Wigan of the 1930s and 1970s have been the subject of much critique by those in and outside of the Northern Soul scene. And yet it is undeniable that there was something 'northern' about the scene. In the mid-1970s it was geographically mostly northern in terms of its venues and participants. Moreover, it did attract coal miners, factory workers and working-class youths from marginal industrial and post-industrial towns on the periphery of Manchester, Leeds, Sheffield and Stoke-on-Trent. It was also a scene that was built on nostalgia and a collective memory of authenticity, collectivism, solidarity, faith and preservation. For all its mythologies, the scene became a late twentieth century addition to popular conceptions of the north with Wigan playing a pivotal role as the centre of northern soul.

Commenting on the homogeneity of Wigan, Orwell noted that in 'a Lancashire cotton-town you could probably go for months on end without hearing an "educated" accent' (Orwell, 1975, p.102). Such homogeneity has been used to both damn and praise Wigan. Russell has argued that there is a tension in conceptions of 'northerness' around notions of 'grimness' and 'laughter'. The north in general and Wigan in particular 'would become not just a place from which comics and comedy came, but, of itself, a comic place' (Russell, 2004, p. 222). Yet Russell sees the Casino as also playing a crucial role in subverting the caricatures of Wigan and Wiganers. In the 1970s, the Casino was a space where the chatter of a multiplicity of northern working-class accents could be heard alongside the rare soul recordings of Detroit and other iconic American cities. Here was something positive that subverted caricatures of the north and 'northerness' and aesthetically drew on sounds, images and cultures that had been created thousands of miles from the industrial north west but shared similar characteristics. In the year that the Casino opened for all-nighters the biographer of the trade union leader Les Cannon stressed that 'Wigan ... could scarcely be called an attractive town' (Cannon and Anderson, 1973, p. 13). Such unattractiveness also became a familiar trope for describing the north which was further engendered in the context of deindustrialisation, rising unemployment and inequality in the late 1970s and 1980 s.

After the closure of the Casino in 1981, subsequent writers endeavoured to follow Orwell's road to Wigan pier. The feminist activist Bea Campbell made her journey in 1982 and used new material to critique Orwell's original observations and the politics of Thatcherism that was leaving dark scars on towns like Wigan through rising poverty, unemployment and the demonization of the poor. Yet, Campbell witnessed the bonds of solidarity, communality and the essence of a 'northern soul' that was being fragmented by deindustrialisation and inequality. Wigan remained a white town but one that still absorbed and celebrated the sounds of black America. Campbell observed that the locality 'only seems to have a Black population on Tuesday nights when the music from the Wigan Pier night-club's jazz-funk DJ draws in young Blacks from as far as the Midlands' (Campbell, 1984, p. 4).

Thirty years after Campbell's journey to Wigan, Northern Soul was resurgent with the local authority celebrating the history of the Casino. This was complemented by a range of books, articles, documentaries and feature films that attempted to reconstruct the energy, force and meaning of Northern Soul. Stuart Maconie presented a light-hearted defence of his 
home town that covered everything from the work, diet, culture and habits of Wiganers, ' $\mathrm{A}$ cosy but marginal place well away from the centres of power ... A place that is forever 1932' (Maconie, 2008, p. 144). For some on the Northern Soul Scene, Wigan will be forever 1973, 1977, 1981 or whichever year symbolised their connection to the club, the music, and collective identity it engendered.

\section{Conclusion}

So, did Wigan have a northern soul? As an archetypal industrial town that has become a touchstone for characterisations and symbols of labour, masculinity, class, communality and working-class culture it conforms to a both an 'imagined' and 'real' sense of 'northerness'. Its associations with Northern Soul have been coincidental, contrived and problematic. However, through Wigan's acceptance and appropriation of the subculture it quite definitely does have a northern soul in both the absolute and figurative sense, which now sits comfortably and probably permanently along with its other iconic 'northern' characteristics'. In the twenty-first century Wigan remains a town built on an industrial past retaining some of the features of a working-class culture built on cotton and coal. The Northern Soul scene has now been firmly established as part of the cornucopia of class identities and cultures that are used to define the recent past of Wigan and its people.

\section{Notes}

1. So named after the ' $M$ ' being the first initial in club owner's surname - Gerry Marshall

2. Many soul fans sought the town's swimming baths as a reviver after the all-nighters

3. The song was one of the 'three before eight played' in ritualistic fashion to herald the end of Wigan Casino all-nighters before 8 am on Sunday morning

\section{Bibliography}

Armitage, C, Armitage, S, Clegg, R, Keegan, A \& Fletcher, R (2017) Interviewed by Stephen Catterall and Keith Gildart 21 August 2017

Armstrong, S (2012) The Road to Wigan Pier Revisited. London: Constable

Blues and Soul Issue 137, June 18-July 1 1974; Issue 234, September 13-26 1977; Issue 261, September 26-October 91978

Brewster, B, \& Boughton, F (2006) Last Night a DJ Saved My Life: The History of the Disc Jockey. New York: Grove Press

Brewster, B \& Boughton, F (2012) The Record Players: The Story of Dance Music Told By History's Greatest DJs. London: Virgin Books 
Campbell, B (1984) The Road to Wigan Pier Revisited: Poverty and Politics in the 1980s. London: Virago

Cannon, O and Anderson, J.R.L (1973) The Road From Wigan Pier: A Biography of Les Cannon. London: Victor Gollanz

Charlson, S (2017) Interviewed by Stephen Catterall, 1 April 2017

Cohen, S (2007) Decline, Renewal and the City in Popular Music Culture: Beyond the Beatles. Aldershot: Ashgate

Cosgrove, S (2016) Young Soul Rebels: A Personal History of Northern Soul. Edinburgh: Birlinn Ltd

Danziger, N (1997) Danziger's Britain: A Journey to the Edge. London: Harper Collins

Gildart, K (2013) Images of England Through Popular Music: Class, Youth and Rock ' $n$; Roll 1955-76. Basingstoke: Palgrave

Hewitt, P (2000) The Soul Stylists: Six Decades of Modernism - From Mods to Casuals. Edinburgh: Mainstream Publishing

Keep on Burning: The Story of Northern Soul (2012), DVD, Odeon Entertainment

Jelbert, S (2010) Tony Palmer's Wigan Casino film comes to DVD, Guardian 15 April 2010 https://www.theguardian.com/music/2010/apr/15/the-wigan-casino-tony-palmer

Retrieved 22 July 2015

Lancashire and Merseyside Development Association (LAMIDA), April 1967, Report, The Decline of the Cotton and Coal Industries of Lancashire, location Manchester

Living for the Weekend (2014), DVD, BBC

Maconie, S (2008) Pies and Prejudice: In Search of the North, London: Random House

Manchester Beat (2017) Room at the Top, http://www.manchesterbeat.com/venues/wigan/roomatthetop/roomatthetop.php

Retrieved 27 July 2017

Mellor, R (2002) 'Hypocritical City: Cycles of urban exclusion' in City of revolution: Restructuring Manchester ', Jamie Peck and Kevin Ward (eds) Manchester: Manchester University Press

Mason, P (2013) Poor-man's Speed: Coming of Age in Wigan's Anarchic Northern Soul Scene, Vice.com.uk http://ww.vice.com/en uk/read/norther-soul-revival-wigan-casinopaul-mason Retrieved 13 August 2014

Milewczyk, A (Al's Soul Shack), (2006), Monaco Ballroom, Hindley, Wigan

http://soulman1949.com/mon/mon.html 23 December 2005

Retrieved 22 July 2017 
Milestone, K (1998) 'Love Factory: The Sites, Practices and Media Relationships of Northern Soul' in The Clubcultures Reader: Readings in Popular Cultural Studies, S. Redhead, D. Wynne \& J O'Conner (eds) Wiley-Blackwell: London

New Musical Express, 29 June 1974

New Soultime, Number 3, n.d. (1976)?

Nowell, D (1999) 'Soul Survivors', Lancashire Life, September 1999

Nowell, D (2002), 'Art from the Soul', Lancashire Life, November 2002

Nowell, D (2015) The Story of Northern Soul: A Definitive history of the Dance Scene that Refuses to Die. London: Portico

Nowell, D (2016) Emailed Completed Questionnaire, 27 July 2016

Orwell, G $(1937,1975)$ The Road to Wigan Pier. Harmondsworth: Penguin

Pilgrim, A (2003) 'Wigan Casino: Memories of the "Heart of Soul"', Past Forward: The Newsletter of Wigan Heritage Service, Issue No 34, Summer 2003

Ritson, M \& Russell, S (1999) The In Crowd: The Story of the Northern \& Rare Soul Scene Volume One. London: Bee Cool Publishing (BCP) Ltd

Russell, D (2004) Looking North: Northern England and the national imagination. Manchester: Manchester University Press

Sanjeck, D (2012) 'Groove Me: Dancing to the Discs of Northern Soul' in Transatlantic Roots Music, J. Terry \& N.A. Wynn (eds), Jackson: University of Mississippi Press

Shaw, D (2003) Casino. London: Bee Cool Publishing (BCP) Limited

Shapiro, P, (2005) Turn the Beat Around: The Secret History of Disco. London: Faber and Faber Ltd

The Swinley (formerly Swinley Labour Club) (2016) Forthcoming Events http://www.theswinley.com/Pages/ArtistsandAttractions.asp Retrieved 7 November 2017

Wigan Casino Art (2017) A visual history of Northern Soul by Chris Gleeson, http://wigancasinoart.co.uk Retrieved 18 July 2017

Wigan Examiner, 11 May 1954

Wigan Observer 27 August 1965, 7 March 1978,15 September 1978, 22 August 2017

Wigan Warriors (2006), Northern Soul Returns to Wigan

http://www.wiganwarriors.com/news/2006-07-12-northern-soul-returns-to-wigan July 12 2006 Retrieved July 212017 
Wiganworld (2017) Photos of Wigan: People http://www.wiganworld.co.uk/album/photo.php?opt=6\&id=21334\&gallery=Friends\&offset $=0$ Retrieved 27 July 2017

Wilson, A (2007) Northern Soul: Music, drugs and subcultural identity. Cullompton: Willan Publishing,

Zani (2017) Rock on - Wigan Casino - The Heavy Rock Venue http://zani.co.uk/zanimusic/item/2708-rock-on-wigan-casino-the-heavy-rock-venue

Retrieved 10 November 2017 